\title{
Synthesis and Preliminary In Vitro Anti-inflammatory Evaluation of Mannich Bases Derivatives of 4'-Methoxy-substituted of Asymmetrical Cyclovalone Analogs
}

\author{
Nur Rahmawati ${ }^{1}$, Hariyanti Hariyanti², Fadlina Chany Saputri ${ }^{1}$, Hayun Hayun ${ }^{1, *}$ \\ 1. Faculty of Pharmacy, Universitas Indonesia, Depok 16424, West Java, Indonesia \\ 2. Faculty of Pharmacy, Universitas Muhammadiyah Prof. DR. HAMKA, Jakarta. 12130 Jakarta
}

\begin{tabular}{|c|c|}
\hline Info Article & ABSTRACT \\
\hline Submitted: 01-12-2019 & Two of Mannich bases derivatives of $4^{\prime}$-methoxy-substituted of \\
\hline Revised: $10-01-2020$ & asymmetrical cyclovalone analog (ACA) ( $\mathbf{2} \mathbf{a}$ and $\mathbf{2} \mathbf{b})$ were synthesized. The \\
\hline Accepted: $20-03-2020$ & synthesized compounds and the other two Mannich bases derivatives of 4'- \\
\hline $\begin{array}{l}{ }^{*} \text { Corresponding author } \\
\text { Hayun Hayun }\end{array}$ & $\begin{array}{l}\text { methoxy-substituted ACA ( } 2 \mathbf{c} \text { and } \mathbf{2} \mathbf{d}) \text { were evaluated for their in-vitro anti- } \\
\text { inflammatory activity preliminary by protein denaturation inhibition } \\
\text { method using a final concentration of } 1.57 \mu \mathrm{M} \text {. The study found that all the }\end{array}$ \\
\hline $\begin{array}{l}\text { Email: } \\
\text { hayun@farmasi.ui.ac.id }\end{array}$ & $\begin{array}{l}\text { Mannich bases exhibited anti-inflammatory potential with inhibition } \\
\text { ranging from } 33.17-42.47 \% \text {. The activity of } \mathbf{2 b}(42,47 \%) \text { and } \mathbf{2} \mathbf{d}(41.90 \%) \\
\text { was higher than that of diclofenac sodium }(35.27 \%) \text { and the parent } \\
\text { compound } \mathbf{1}(38.16 \%) \text {. As a conclusion, } \mathbf{2 b} \text { and } \mathbf{2 d} \text { have a prospect as a } \\
\text { potential candidate for an anti-inflammatory agent. Further study should be } \\
\text { done using more specific methods. }\end{array}$ \\
\hline
\end{tabular}

Keywords: Mannich bases derivatives, asymmetrical, ayclovalone, synthesis, in-vitro anti-inflammatory, protein denaturation.

\section{INTRODUCTION}

Curcumin is well-documented to have antiinflammatory activity with low toxicity. However, clinical usage of the compound is limited due to its stability and bioavailability (Prasad et al. 2014; Anand et al., 2008; Wang et al., 1997). The monocarbonyl analogs of curcumin (MACs), such as cyclovalone, showed a more stable chemical structure and better pharmacokinetic profile. Several of them were more active as antiinflammatory agents than curcumin. (Liang et al., 2008; Zhao et al., 2013; Lamperti et al., 2014; Zhao et al., 2015)..

In the past few years, some asymmetrical MACs were prepared, and among them indicated potent biological activity as anti-inflammation (Zhang et al., 2014a; Zhang et al., 2014b; Aluwi et al., 2016). Introduction of morpholine Mannich base moiety into asymmetrical MACs bearing a cyclohexanone linker (= asymmetrical cyclovalone analogs, ACA) (Figure 1), increased the antiinflammatory activity of the parent compound. 5Morpholinomethyl-4'-methoxy ACA showed the highest activity, which almost comparable to diclofenac sodium (Putri et al., 2018). Further investigation found that 5-dimethylaminomethyl of
ACA (Figure 1, 4'- $\mathrm{R}=\mathrm{H}$ ) exhibited antiinflammatory about four-fold than curcumin and equal to diclofenac sodium (Hayun et al., 2019). However, the anti-inflammatory activity of Manncih bases derivatives of 4'-methoxysubstituted of ACA has not elucidated yet.<smiles>[R]c1ccc(/C=C2\CCC/C(=C\c3ccc(O)c(OC)c3)C2=O)cc1</smiles>

Figure 1. Asymmetrical Cyclovalone Analogs (ACA) (Putri et al., 2018; Hayun et al., 2019)

Hence, as a continuation of the study in exploring the anti-inflammatory activity of Mannich bases derivatives of ACA, in the present study, we synthesized 5-dimethylaminomethyl-4'-methoxy ACA (2a) and 5- $(\mathrm{N}-$ methylpiperazino)methyl-4'-methoxy ACA (2b) (Figure 2). The synthesized compounds and the other two Mannich bases derivatives of 4'methoxy-substituted ACA (2c and 2d) then were evaluated for their preliminary in-vitro antiinflammatory activity. 


\section{MATERIAL AND METHODS}

2,6-(4'-Methoxybenzylidene-4-hydroxy-3methoxybezylidene)cyclohexanone $\left(=4^{\prime}\right.$-methoxy ACA) (1), 5-diethylaminomethyl-4'-methoxy ACA (2c), 5-morpholinomethy-4'-methoxy ACA (2d), and cyclovalone, were donated by earlier researchers (Hayun et al., 2017; Prasetyaningrum et al., 2018; and Putri et al., 2018). Diclofenac sodium was obtained from PT Kimia Farma, Indonesia, while other chemicals and solvent were supplied from chemical suppliers of Sigma-Aldrich or Merck. The compounds' melting point was measured by the melting point apparatus (Stuart Scientific, UK), infrared spectra and NMR spectra were recorded by FT-IR Spectrometer (Agilent Technologies, USA) and NMR spectrometer (Agilent Technologies, USA) respectively. While the mass spectra were recorded by LC-MS with ESI (+) mode (UNIFI, Waters, USA).

Synthesis of Mannich Bases derivatives of 4'methoxy ACA (2a and $2 \mathrm{~b}$ )

The compounds $\mathbf{2 a}$ and $\mathbf{2} \mathbf{b}$ were synthesized using the method for preparation of $\mathbf{2 c}$ and $\mathbf{2 d}$ reported previously (Prasetyaningrum et al., 2018, Putri et al., 2018). A cooled solution in ethanol of $\mathbf{1}$ (2 mmol) was stirred and added a solution in ethanol of dimethylamine (for 2a) or 1methylpiperazine (for 2b) $(6 \mathrm{mmol})$ and formaldehyde solution ( $6 \mathrm{mmol})$. The mixture was further stirred for 30 minutes at r.t., then refluxed for $3 \mathrm{~h}$ (for $\mathbf{2 a}$ ) and $6 \mathrm{~h}$ (for $\mathbf{2 b}$ ) until the reaction was completed (TLC monitoring). After that, the products were isolated and then purified using a column chromatography technique to get $\mathbf{2 a}$ and $\mathbf{b}$.

\section{Preliminary in-vitro anti-inflammatory Evaluation.}

The evaluation was done using inhibition of albumin denaturation technique, as reported previously with minor modification (Putri et al., 2018). Mixture of $0.5 \mathrm{~mL}$ of standard or test compounds solution in methanol (15.72 uM) or solvent (for control) and $4.5 \mathrm{~mL}$ Bovine Saline Albumin (BSA) 0,5\% in tris-buffer saline pH 6.3 was incubated at $37^{\circ} \mathrm{C}$ for $15 \mathrm{~min}$, then heated at $70^{\circ} \mathrm{C}$ in a water bath for $5 \mathrm{~min}$, and cooled to reach room temperature. The turbidity was measured at $660 \mathrm{~nm}$. The inhibition (\%) of the denaturation was calculated with the formula:

$\%$ inhibition $=\left[\mathrm{Ac}-\frac{\mathrm{As}}{\mathrm{Ac}}\right] \times 100 \%$

where Ac was absorbance of control; As was absorbance with sample addition.

\section{RESULT AND DISCUSSION Chemistry}

(Figure 2).

Scheme of the synthesis of compound $\mathbf{2 a - b}$

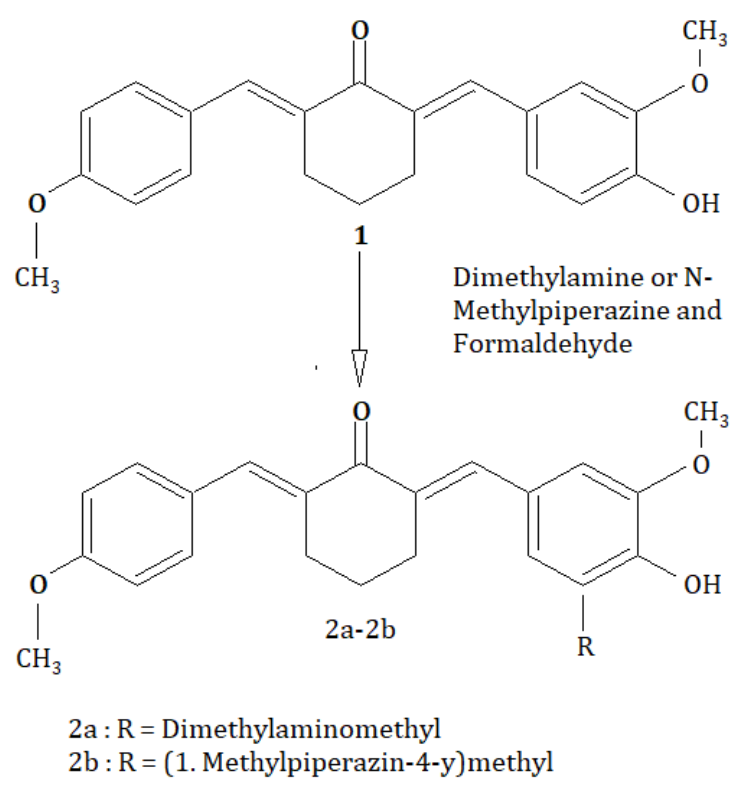

Figure 2. Scheme of the synthesis of Mannich bases derivatives of 4'-methoxy-substituted ACA

Infrared, ${ }^{1}$ proton, and ${ }^{13}$ carbon NMR and mass spectral data obtained were presented in Table II. The infrared spectra $\mathbf{2 a}$ and $\mathbf{2 b}$ (Figures 3) showed the bands of $\mathrm{C}-\mathrm{O}-\mathrm{C}$ and $\mathrm{C}-\mathrm{N}$ at $1,246-$ $1.023 \mathrm{~cm}^{-1} ; \quad \mathrm{C}-\mathrm{H}$ aliphatic at 2.935-2.829, while the a,ß-unsaturated carbonyl groups, the $\mathrm{C}=\mathrm{C}$ aromatic or ethylenic and alkyl were observed as strong band peaks at $1.658-1.507$ and $1.459 \mathrm{~cm}^{-1}$, respectively. The ${ }^{1}$ proton NMR (Figures 4), the protons of methylene connecting $\mathrm{N}$ of dimethylamine or N-methylpiperazine to aromatic ring appeared as a singlet at $3.71 \mathrm{ppm}$. Six protons from dimethylamine group in $\mathbf{2 a}$ appeared as singlet peak at $2.34 \mathrm{ppm}$, eight protons from piperazine group in $\mathbf{2 b}$ appeared as multiplet peak at 2.99ppm, and three protons of $\mathrm{N}$-methylpinerazine group in $\mathbf{2} \mathbf{b}$ appeared as a singlet at $2.31 \mathrm{ppm}$. While, the two protons from the ethenyl chain appeared as two singlets at $7.61-7.67 \mathrm{ppm}(1 \mathrm{H}$, respectively) confirming the structures were asymmetric (Silverstein et al., 2005). The structures elucidation was supported further by ${ }^{13}$ carbon NMR (Figures 5 and mass spectra (Figures 6). All data confirmed full agreement with the structures expected. 
Table I. Physical and spectral data of compound $\mathbf{2 a}$ and $\mathbf{2 b}$

\begin{tabular}{|c|c|c|c|c|c|}
\hline \multirow[b]{2}{*}{ Compd } & \multirow[b]{2}{*}{ Physical } & \multicolumn{4}{|c|}{ Spectra } \\
\hline & & $\begin{array}{l}\text { Infra red } \\
\left(\mathrm{cm}^{-1}\right)\end{array}$ & $\begin{array}{c}\text { 1Proton NMR, } \\
\delta(\mathrm{ppm})\end{array}$ & $\begin{array}{c}{ }^{13} \text { Carbon } \\
\text { NMR, } \delta(p p m)\end{array}$ & $\begin{array}{c}\text { Massa }\left(\mathrm{M}+\mathrm{H}^{+}\right) \\
(\mathrm{m} / \mathrm{z})\end{array}$ \\
\hline $2 a$ & $\begin{array}{l}\text { Red } \\
\text { crystal, } \\
\text { mp. } 100- \\
102^{\circ} \mathrm{C}\end{array}$ & $\begin{array}{l}2,931-2,829, \\
1,658,1,554, \\
1,507,1,459, \\
1,246,1,138, \\
\text { and } 1,023 .\end{array}$ & $\begin{array}{l}7.67(1 \mathrm{H}, \mathrm{s}), 7.62(1 \mathrm{H}, \mathrm{s}), \\
7.50(2 \mathrm{H}, \mathrm{d}), 7.07(1 \mathrm{H}, \mathrm{s}), \\
7.03(2 \mathrm{H}, \mathrm{d}), 6.91(1 \mathrm{H}, \mathrm{s}), \\
3.86(3 \mathrm{H}, \mathrm{s}), 3.83(3 \mathrm{H}, \mathrm{s}), \\
3.72(2 \mathrm{H}, \mathrm{s}), 2.94 \\
(4 \mathrm{H}, \mathrm{m}), 2.34(6 \mathrm{H}, \mathrm{s}), \\
1.78(2 \mathrm{H}, \mathrm{m})\end{array}$ & $\begin{array}{l}189(1 C), 162 \\
(1 C), 150 \& \\
149(2 C), 137- \\
115(13 C), 63 \\
(1 C), 55 \& 56 \\
(2 C), 45(2 C), \\
28-23(3 C)\end{array}$ & $\begin{array}{l}\text { Found: } 408.21680 \\
\text { Calc for neutral } \\
\text { mass of } \\
\text { C25H29NO4 = } \\
407.20966 ; \text { Mass } \\
\text { Error = }-0.3 \mathrm{mDa}\end{array}$ \\
\hline $2 b$ & $\begin{array}{l}\text { Yellow } \\
\text { crystal, } \\
\text { mp. } 123- \\
126^{\circ} \mathrm{C}\end{array}$ & $\begin{array}{l}2,935-2,864, \\
1,655,1,589, \\
1,508,1,459, \\
1,246,1,142, \\
\text { and } 1,023 .\end{array}$ & $\begin{array}{l}7.67(1 \mathrm{H}, \mathrm{s}), 7.62(1 \mathrm{H}, \mathrm{s}), \\
7.46(2 \mathrm{H}, \mathrm{d}), 7.01(1 \mathrm{H}, \mathrm{s}), \\
6.99(1 \mathrm{H}, \mathrm{s}), 6.97(2 \mathrm{H}, \mathrm{d}), \\
3.84(3 \mathrm{H}, \mathrm{s}), 3.83(3 \mathrm{H}, \mathrm{s}), \\
3.75(2 \mathrm{H}, \mathrm{s}), \\
2.92(4 \mathrm{H}, \mathrm{m}), 2.59 \\
(8 \mathrm{H}, \mathrm{m}), 2.30(3 \mathrm{H}, \mathrm{s}), \\
1.80(2 \mathrm{H}, \mathrm{m})\end{array}$ & $\begin{array}{l}192(1 C), 161 \\
(1 C), 149 \& \\
148(2 C), 138- \\
114(13 C), 59 \\
(1 C), 55 \& 56 \\
(2 C), 53 \& 56 \\
(4 C), 46(1 C) \\
30-24(3 C)\end{array}$ & $\begin{array}{l}\text { Found: } 463.25921 \\
\text { Calc for neutral } \\
\text { mass of } \\
\text { C28H34N204 = } \\
462.25186 \text {; Mass } \\
\text { Error }=-0.3 \mathrm{mDa}\end{array}$ \\
\hline
\end{tabular}

$2 \mathbf{a}$

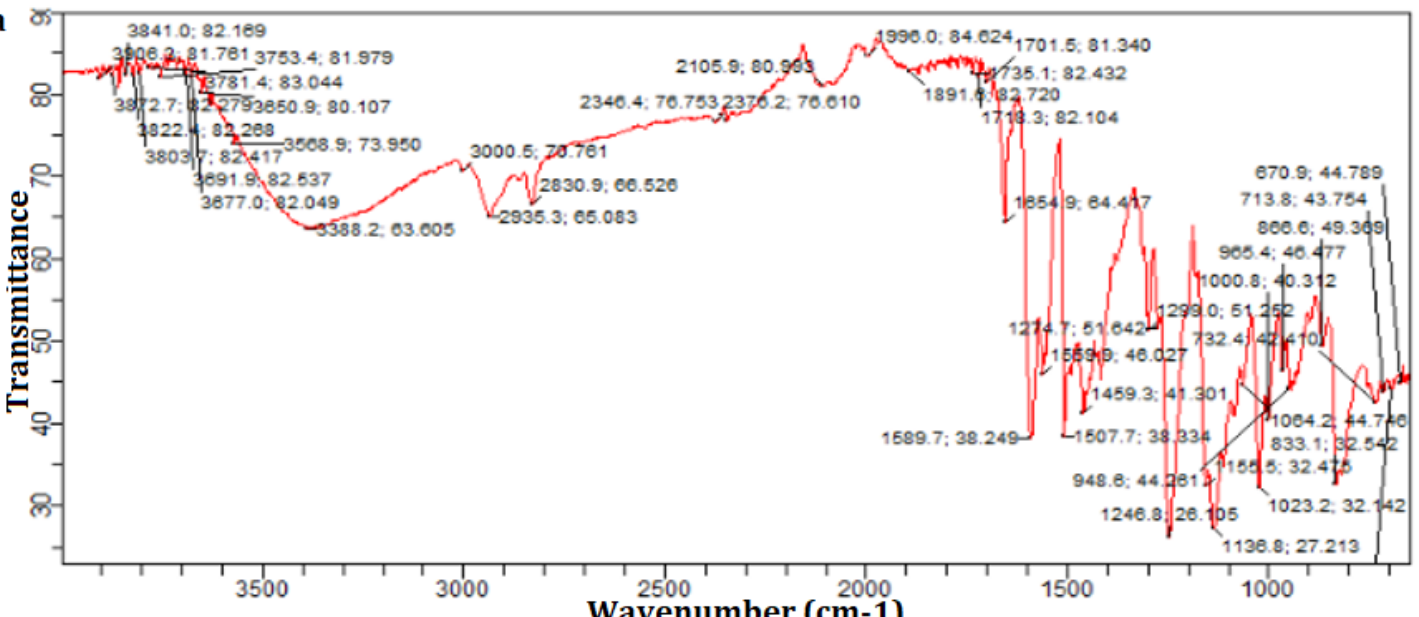

$2 b$

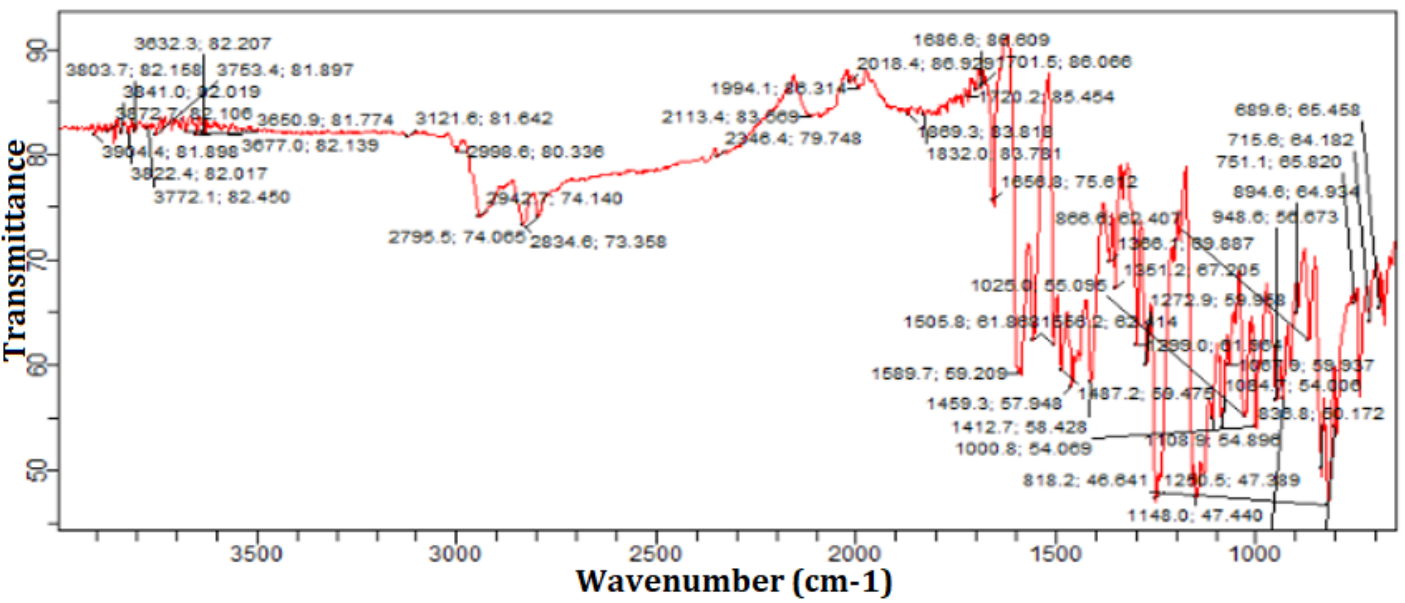

Figure 3. Infra red spectrum of $\mathbf{2 a}$ and $\mathbf{2 b}$ 

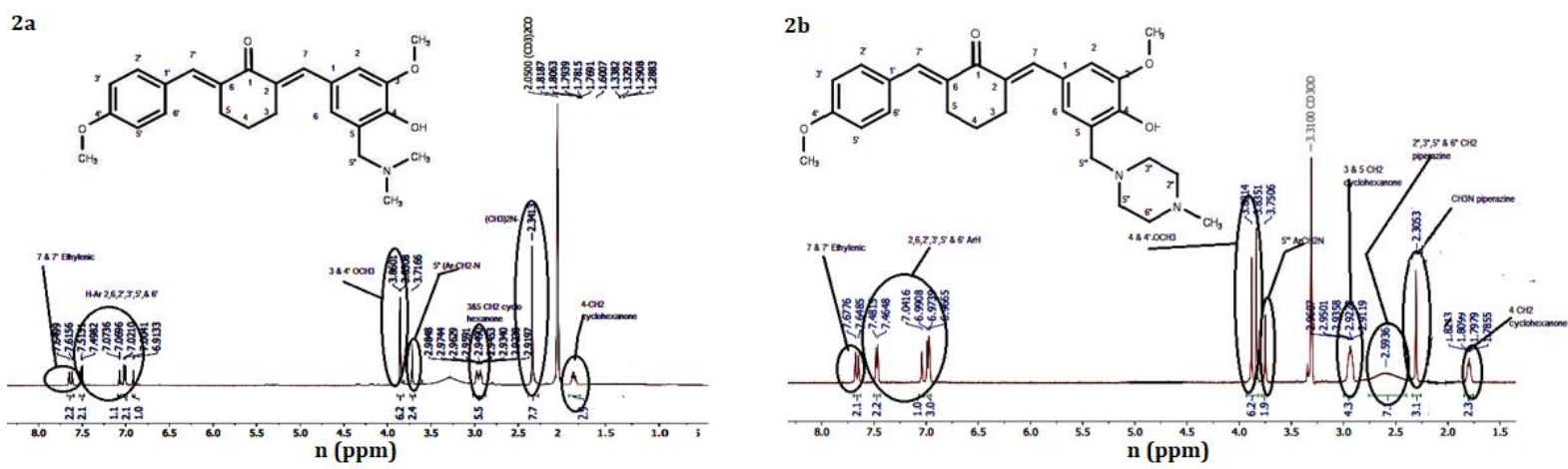

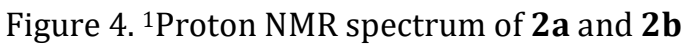
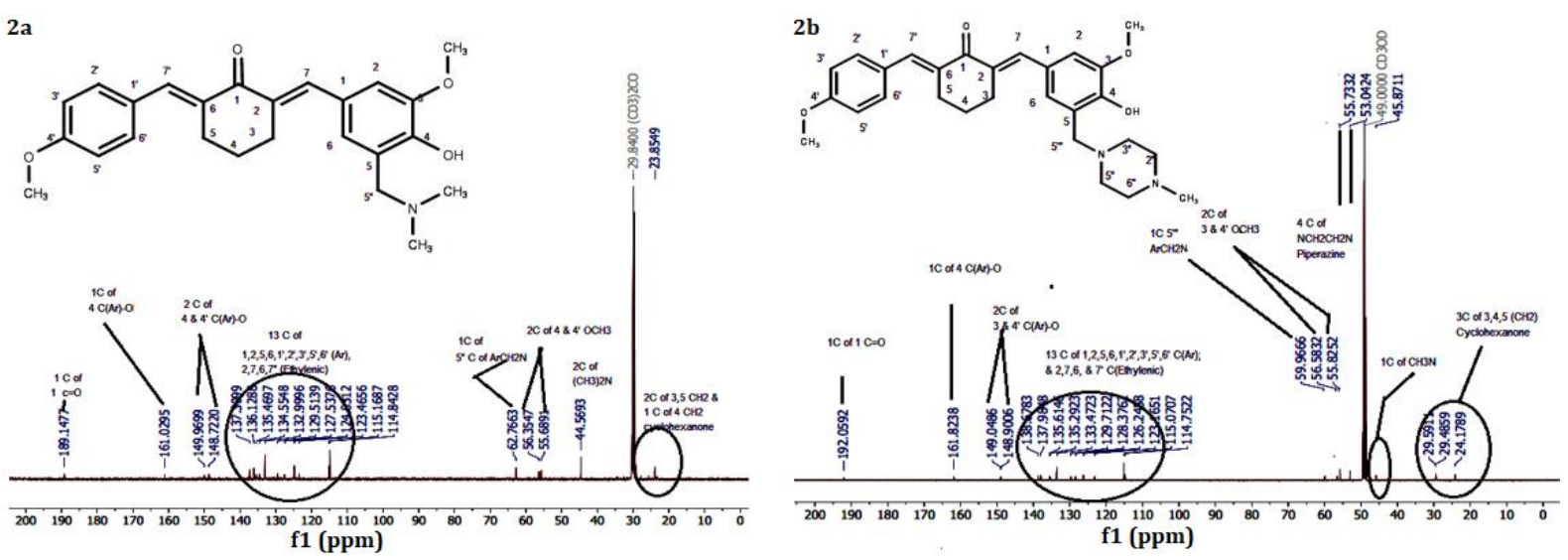

Figure $5 .{ }^{13}$ Carbon NMR spectrum of $\mathbf{2 a}$ and $\mathbf{2 b}$
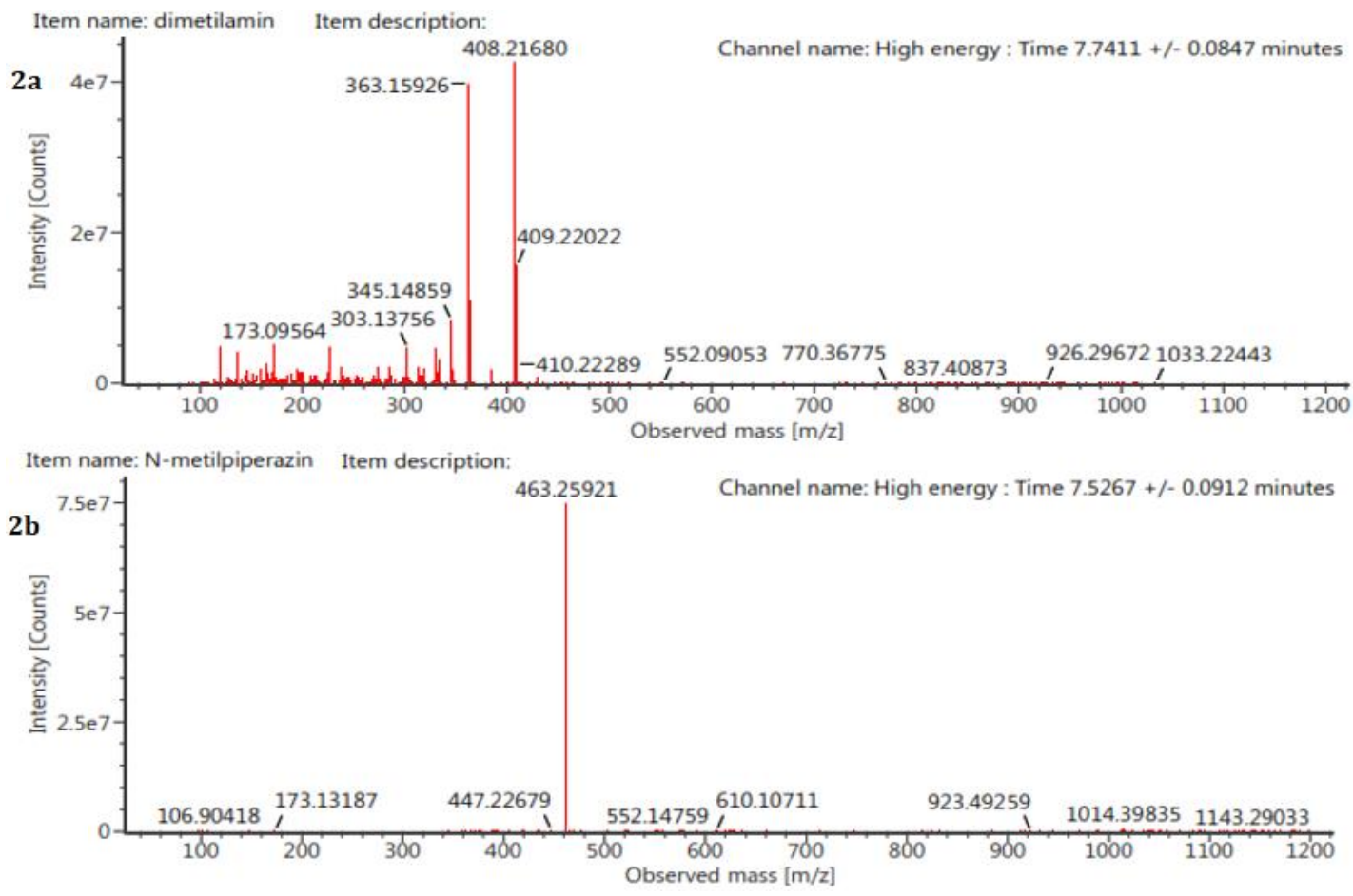

Figure 6. Mass spectrum of $\mathbf{2 a}$ and $\mathbf{2 b}$ 


\section{In-vitro Anti-inflammatory activity}

Protein denaturation in vivo is one of the causes of inflammation. One of the mechanisms of antirheumatic activity of NSAIDs is by inhibiting this denaturation (Umapathy et al. 2010; Gunathilake et al., 2018). Denaturation of protein can be induced by UV or heat. The denaturation is making protein aggregation, which can lead to the production of superoxide and nitric oxide by macrophages, which stimulates inflammation (Guzik et al., 2003). Compounds inhibiting the heatinduced protein denaturation are considered to have potential anti-inflammatory activity (Chandra et al. 2012; Jagtap et al., 2011).

Table II. Inhibition (\%) of heat-induced albumin denaturation by $1.57 \mu \mathrm{M}$ of the test compounds.

\begin{tabular}{ccc}
\hline Compound & \multicolumn{2}{c}{ Inhibition (\%) $\mathbf{\pm S D}$} \\
\hline $\mathbf{1}$ & 38.16 & 0.14 \\
$\mathbf{2 a}$ & 33.17 & 0.06 \\
$\mathbf{2 b}$ & 42.47 & 0.02 \\
$\mathbf{2 c}$ & 38.86 & 0.04 \\
$\mathbf{2 d}$ & 41.90 & 1.63 \\
Cyclovalone & 19.64 & 0.09 \\
Diclofenac Sodium & 35.27 & 0.02 \\
\hline
\end{tabular}

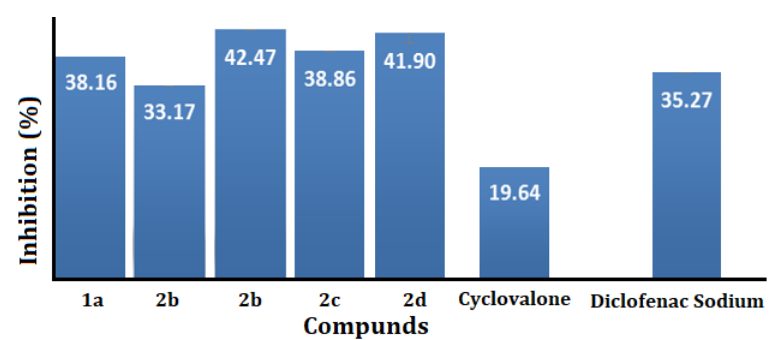

Figure 7. Inhibition \pm SD $(\%)(n=3)$ of heatinduced albumin denaturation the Mannich base derivatives of 4'-methoxy-substituted of asymmetrical cyclovalone analogs (ACA) (2a-d) compared to the parent compound (1), cyclovalone and sodium diclofenac at a final concentration of $1.57 \mu \mathrm{M}$.

The preliminary activity of the synthesized compounds (Table II and Figure 7). At a final concentration of $1.57 \mu \mathrm{M}$ indicated that all the Mannich bases inhibited the heat-induced protein denaturation ranging from $33.17-42.47 \%$. This study found that the activity of $2 \mathbf{b}[5-(\mathrm{N}-$ methylpiperazino)methyl-4'-methoxy ACA] (42.47\%) and 2d (5-morpholinomethyl-4'methoxy ACA) (41.90\%) was higher than that of diclofenac sodium (35.27\%), the parent compound
1 (38.16\%), and cyclovalone (19.64\%). It was in line with the result of the introduction of the Mannich bases to dehydrozingerone reported earlier (Hayun et al., 2018). Therefore, the compounds have a prospect as a potential candidate for an anti-inflammatory agent. However, to ensure their biological activities, further study should be done using more specific methods.

\section{CONCLUSION}

Two Mannich base derivatives of asymmetrical cyclovalone analogs (ACA) were synthesized successfully. Their preliminary in-vitro anti-inflammatory evaluation indicated that the compound 2b [5-(N-methylpiperazino)methyl-4'methoxy ACA] and 2d (5-morpholinomethyl-4'methoxy ACA) exhibited the highest activity. Their biological activities were higher than diclofenac sodium. However, further study should be done using more specific methods.

\section{ACKNOWLEDGMENT}

This work was supported by Universitas Indonesia (PITTA B, Research Grant 2019). Thank Laboratory of Organic Chemistry, Instititut Teknologi Bandung, Indonesia, for recording NMR spectra; and to the Research Center for Chemistry, the Indonesian Institute of Sciences, Serpong, Indonesia, for recording mass spectra.

\section{REFERENCES}

Aluwi MFMF., Rullah K., Yamin BM., Leong SW., Bahari MNA., et al., 2016. Synthesis of unsymmetrical monocarbonyl curcumin analogues with potent inhibition on prostaglandin E2 production in LPS induced murine and human macrophages cell lines. Bioorg Med Chem Let. 26(10):2531-2538. http://doi.org/10.1016/j.bmcl.2016.03.092

Anand P., Thomas SG., Kunnumakkara AB., Sundaram C., Harikumar KB. et al., 2008. Biological activities of curcumin and its analogues (congeners) made by man and mother nature. Biochem Pharmacol. 76:1590-1611.

http://doi.org/10.1016/j.bcp.2008.08.008.

Chandra S., Chatterjee P, Dey P, Bhattacharya S. 2012. Evaluation of in vitro antiinflammatory activity of coffee against the denaturation of protein. Asian Pac J Trop Biomed. 2:S178-S180. https://doi.org/10.1016/S22211691(12)60154-3 
Gunathilake KDPP., Ranaweera KKDS., Rupasinghe HPV. 2018. In Vitro Anti-Inflammatory Properties of Selected Green Leafy Vegetables. Biomedicines 6, 107. http://doi.org/10.3390/biomedicines6040 107

Guzik TJ., Korbut R., Adamek-Guzik T. 2003. Nitric oxide and superoxide in inflammation and immune regulation. J Physiol Pharmacol. 54(4):469-487.

https://www.ncbi.nlm.nih.gov/pubmed/14 726604

Hayun H., Maggadani BP., Kurnia A., Hanifah A., Yuliandi M., et al., 2019. Anti-Inflammatory And Antioxidant Activity of Synthesized Mannich Base Derivatives of (2E,6E)-2-[(4Hydroxy-3-methoxyphenyl)methyl-idene]6-(phenylmethylidene)cyclohexan-1-one. Int J App Pharm. 11 (Special Issue1):246250.

http://dx.doi.org/10.22159/ijap.2019.v11s $\underline{1.19448}$

Hayun H., Jatmika C., Purwati EM., Salim S., Kurniawan R. et al. 2017. Synthesis and Free Radical-scavenging Activities of Di-Mannich Bases of Cyclovalone Derivatives. Orient J Chem. 33(6):2742-57. http://dx.doi.org/10.13005/ojc/330607

Hayun H., Arrahman A., Purwati EM., Yanuar A., Fortunata F., Suhargo F. et al. 2018. Synthesis, anti-inflammatory, and antioxidant activity of Mannich bases of dehydrozingerone derivatives. J Young Pharm.10:s6-10:56-60. http://doi.org/10.5530/jyp.2018.2s.2

Jagtap VA., Agasimundim YS., Jayachandran E., Sathe BS. 2011. In vitro anti-inflammatory activity of 2-amino-3-(substituted benzylidinecarbohydrazide)-4,5,6,7- tetrahydrobenzothiophenes. J Pharm Res. 4(2):378-9.

http://jprsolutions.info/newfiles/journalfile-56cc7064d2aa84.22735300.pdf

Lamperti M., Maspero A., Tonnesen HH., Bondani M., Nardo L. 2014. Elucidation of the relationships between $\mathrm{H}$-bonding patterns and excited state dynamics in cyclovalone. Molecules. 19(9):13282-13304. https://doi.org/10.3390/molecules190913 $\underline{282}$

Liang G., Li X., Chen L., Yang S., Wu X., et al., 2008. Synthesis and anti-inflammatory activities of mono-carbonyl analogues of curcumin.
Bioorg Med Chem Lett. 18(4): 1525-1529. http://doi.org/10.1016/j.bmcl.2007.12.068

Prasad S., Tyagi AK., Aggarwal BB. 2014. Recent developments in delivery, bioavailability, absorption and metabolism of curcumin: the golden pigment from golden spice. Cancer Res Treat. 46(1):2-18. https://doi.org/10.4143/crt.2014.46.1.2

Prasetyaningrum PW., Bahtiar A., Hayun H. 2018. Synthesis and cytotoxicity evaluation of novel asymmetrical mono-carbonyl analogs of curcumin (AMACs) against Vero, HeLa, and MCF7 Cell Lines. Sci Pharm. 86(2):25. http://doi.org/10.3390/scipharm8602002 $\underline{5}$

Putri TN., Bachtiar A., Hayun H. 2018. Synthesis, antioxidant, and antiinflammatory activity of morpholine Mannich base of AMACs ((2E,6E)-2-(\{4-hydroxy-3-[morpholin-4yl)methyl] phenyl\}methylidene)(phenylmethylidene)c yclohexan-1-one) and its analogs. $J A p p$ Pharm Sci. 8:19-25. http://doi.org/10.7324/JAPS.2018.8503

Silverstein RM., Webster FX., Kiemle DJ. 2014. Spectrometric Identification of Organic Compounds. 7th ed. New York, USA: John Wiley and Sons, Inc.

Umapathy E., Ndebia EJ., Meeme A., Adam B., Menziwa P., et al. 2010. An experimental evaluation of Albuca setosa aqueous extract on membrane stabilization, protein denaturation and white blood cell migration during acute inflammation. J Med Plants Res. 4:789-795. http://doi.org/10.5897/JMPR10.056

Wang YJ., Pan MH., Cheng AL., Lin LI., Ho YS., et al., 1997. Stability of curcumin in buffer solutions and characterization of its degradation products. J Pharm Biomed Anal. 1997;

15:1867-1876.

http://doi.org/10.1016/s07317085(96)02024-9

Zhao C., Liu Z., Liang G. 2013. Promising curcuminbased drug design: Mono-carbonyl analogues of curcumin (MACs). Curr Pharm Des. 19:2114-2135. http://doi.org/ $\underline{10.2174 / 1381612811319110012}$

Zhao C., Zhang Y., Zou P., Wang JJ., He W., et al., 2015. Synthesis and biological evaluation of a novel class of curcumin analogs as antiinflammatory agents for prevention and treatment of sepsis in mouse model. Drug 
Des Dev Ther. 9:1663-1678. https://doi.org/10.2147/DDDT.S75862

Zhang Y., Zhao L., Wu J., Jiang X., Dong L., et al., 2014a. Synthesis and evaluation of a series of novel asymmetrical curcumin analogs for the treatment of inflammation. Molecules. 19:7287-7307. https://doi.org/10.3390/molecules190672 $\underline{87}$

Zhang Y., Jiang X., Peng K., Chen C., Fu L., et al., 2014 b. Discovery and evaluation of novel antiinflammatory derivatives of natural bioactive curcumin. Drug Des Devel Ther. 8:2161-2171.

https://doi.org/10.2147/DDDT.S69914 